\title{
The Effect of Introducing HHO Gas into the Intake Manifold of Spark Ignition Engine (SIE)
}

\author{
Haroun Hassan \\ Mechanical Engineering \\ Department \\ Faculty of Energy Engineering, \\ Aswan University \\ Aswan, Egypt \\ harounelqwedy73@gmail.com
}

\author{
W. A. Aissa \\ Mechanical Engineering \\ Department \\ Faculty of Energy Engineering, \\ Aswan University \\ Aswan, Egypt \\ waessa@energy.aswu.edu.eg
}

\author{
M. Shaban Eissa \\ Mechanical Engineering \\ Department \\ Faculty of Energy Engineering, \\ Aswan University \\ Aswan, Egypt
}

\author{
H. Abdel-Mohsen \\ Mechanical Engineering \\ Department \\ Faculty of Energy Engineering, \\ Aswan University \\ Aswan, Egypt
}

\begin{abstract}
- one of the most effective solutions for improving the performance and reducing the emission of spark ignition engine is introducing a hybrid fuel with gasoline. Hydroxy gas (HHO) that is generated from water electrolyzes process has a significant effect in enhancing the thermal efficiency and reducing fuel consumption rate and the resulted combustion emissions of SI engine. Because HHO gas has significant advantages rather than fossil fuels. In this study a fuel dry cell is constructed and tested in different concentrations of electrolysis water solutions and with alternating the number of neutral plates, to obtain the most economic, safe and suitable cell for the desired engine operation conditions . The engine used is a $183 \mathrm{CC}$ single cylinder air cooled (Robin EY 20-3) without any change in engine construction. The load used for this purpose is a centrifugal water pump with a maximum delivery flow rate of $520 \mathrm{~L} / \mathrm{min}$. First, the engine is allowed to run separately without the cell under different speeds of $1200,1500,2000,2500,3000$ and $3500 \mathrm{rpm}$, then the cell is connected to the engine. Many different operating parameters are measured such as pump flow rate, fuel consumption rate, water pressure, exhaust temperature, and engine emissions; HC and CO. The experimental results show that increasing the concentration of electrolysis solution or reducing the number of neutral plate increased the production rate of the gas, but it has undesirable effect on increasing the temperature of the cell. And for engine performance the average enhancement of engine efficiency, reductions in break specific fuel consumption, reduction in $\mathrm{CO}$ and $\mathrm{HC}$ emissions are $5.44 \%, 16.9 \%, 4.8 \%$, and $5.5 \%$, respectively
\end{abstract}

Keywords-HHO, engine, performance, emissions

\section{INTRODUCTION}

Harmful pollutants which are result of the emissions of burning fossil fuels have negative impacts on the environment and lives[1]. Some researches focused on reducing the emission and fuel consumption in internal combustion engine. Wang et al.[2] try to improve the gasoline engine by adding HHO mixture. They studied the effect of the addition of hydrogen and HHO with three volume fractions $(0,2 \%$ and $4 \%)$ with changing the excess air ratio on the engine performance and emission at $1400 \mathrm{rpm}$ and a MAP of $61.5 \mathrm{kpa}$ conditions., the addition of hydroxygen in gasoline engine increases the thermal efficiency, the brake mean effective pressure and NOx emission than the traditional engine and hybrid gasoline with hydrogen engine at lean conditions and decreases $\mathrm{CO}$ emission. EL-Kassaby et al.[3] Fabricated an HHO fuel dry cell. They used different catalyst type with different concentration sodium hydroxide and potassium hydroxide. They stated that, the addition of HHO gas increased the thermal efficiency by $10 \%$ and make a reduction in fuel consumption, hydrocarbons, carbon monoxide and nitrogen oxides by $34 \%, 14 \%, 18 \%$ and $15 \%$ respectively. Krishna.[4] studied the effect of introducing HHO gas on the performance and emission of spark ignition four stroke single cylinder engine at a speed range of 700 to $1500 \mathrm{rpm}$. The results show that, brake thermal efficiency increased by $5-10 \%, 5 \%$ to $12 \%$. And a reduction of $20 \%$ and $62 \%$ in Carbon monoxide and NOx respectively. Rajasekaran et al. [5] tested a single Cylinder engine run with two fuels gasoline and liquefied petroleum gas by introducing $\mathrm{HHO}$ gas into the two engine cases. Introducing $\mathrm{HHO}$ gas resulted in decreasing fuel consumption and emissions. Experimental results show that, fuel consumption reduced by $9.6 \%$ and $15.7 \%$, CO reduced by $27.5 \%$ and $52.1 \%$. Sunil et al.[6] did an experiment on a single cylinder air cooled $100 \mathrm{CC}$ ignition petrol engine with introducing HHO gas. They stated that HHO gas has a significant effect in engine performance and that the engine became more smooth and stable during operation and less emission produced. Musmar and Al-Rousan.[7] Studied the effect of hydroxy gas on the emissions of gasoline Honda G200 (197 CC) engine. The result showed that, introducing $\mathrm{HHO}$ gas into the intake manifold of the engine reduced $\mathrm{NOx}$ by $50 \%$ and $\mathrm{CO}$ by $20 \%$ beside an enhancement in engine efficiency. Al-Rousan.[8] did his experiment on the same engine with two different cell conditions depending on the size of piston area. Yilmaz and Aydeo. [9] studied the effect of $\mathrm{HHO}$ gas on $\mathrm{CI}$ engine their results showed that, engine torque increased by $19.1 \%, \mathrm{HC}$ and $\mathrm{CO}$ reduced by $5 \%$ and $13.5 \%$ respectively. Karagoz.[10] tested diesel engine with different levels $[0 \%, 40 \%$ and $75 \%]$ of hydrogen at the condition of $1300 \mathrm{rpm}$ and full load operation. Their results recorded that, increasing hydrogen level increased break thermal efficiency by $1.26 \%$ and $2.1 \%$, carbon monoxide decreased by $25 \%, 60 \%$ and hydrocarbons decreased by $30 \%, 60 \%$. Uludamar et al. [11] studied the effect HHO gas on the vibration of diesel engine fueled with different diesel biodiesel blends. Nabil and Dawood.[12] designed, fabricated and tested experimentally an HHO fuel dry cell and they used it in two engines; $150 \mathrm{CC}$ with carburetor and $1300 \mathrm{CC}$ with Electronic Control Unit (ECU).Theie 
results showed that, a reduction of $14.8 \%$ and $16.3 \%$ for $150 \mathrm{CC}$ engine and $1300 \mathrm{CC}$ respectively, and the emissions were reduced by $33 \%$ and $24.5 \%$ in $\mathrm{CO}$ and $27.4 \%$ and $21 \%$ reduction in $\mathrm{HC}$ for $150 \mathrm{CC}$ and $1300 \mathrm{CC}$ engines respectively. Ismail et-al. [13] conducted an experiment on a $1500 \mathrm{CC}$ SI engine with $\mathrm{HHO}$ gas generator. Their results showed that, $\mathrm{CO}, \mathrm{HC}$, and $\mathrm{CO}_{2}$ were reduced by $17 \%, 27 \%$, and $15 \%$ respectively and a reduction of $17 \%$ in fuel consumption rate. Bari and Esmaeil. [14] conducted an experiment on CI engine to study the effect of HHO gas on the engine, they stated that under variable load and constant engine speed, thermal efficiency increased from $32.0 \%$ to $34.6 \%, 32.9 \%$ to $35.8 \%$ and $34.7 \%$ to $36.3 \%$ at $19 \mathrm{~kW}, 22$ $\mathrm{kW}$ and $28 \mathrm{~kW}$ power respectively in the case of using $4.84 \%, 6.06 \%$, and $6.12 \%$, total diesel equivalent of $\mathrm{H} 2 / \mathrm{O} 2$ mixture. Conker.[15] designed an electronic control circuit using pulse width modulation (PWM) system to control production rates of the cell according to engine operation demand. Al-Rousan and Musmar.[16] studied the effect of anodes-cathodes inter-distances on the performance of SI engine. They stated that, in cases of $10 \mathrm{~mm}$ cathode-anode plates distance, $\mathrm{HC}$ and $\mathrm{CO}$ reduced to about $40 \%$ at different engine speeds.

In this study a simple fuel dry cell was manufactured and tested in different operation conditions, then it conducted to the engine to select the suitable cell operating condition.

\section{EXPERIMENTAL SET UP}

\section{A. HHO GENERATOR}

\section{- CELL.}

The cell used in this experiment is a dry fuel cell shown in Fig. 2, it has 21 plates (made of stainless steel-grade $316 \mathrm{~L}$ ) $12 \times 12 \times 0.1 \mathrm{~cm}$ thickness. Stainless steel has good electric conductivity and it can resist rust formation. The distance between two adjacent plates is limited to $2 \mathrm{~mm}$ by black insulator rubber gasket, so the electrolysis will be located between the plates. The cover plate $15 \times 15 \times 2 \mathrm{~cm}$ thickness is made of reinforced wood, wood is better than acrylic ,it can wisest the tighten torque of the bolts in order to prevent any leakage between the plate and the gasket in the cell. Another two plates of stainless steel $15 \times 15 \times .2 \mathrm{~cm}$ thickness are located between the two ends of the plate's arrangement and the wood cover plate to insulate wood from water and also for pipe connections. Fig.1. shows the shape of the plate, the plate has to holes, the highest hole will be in the front of outlet port after assembling the cell and the second hole will be facing the inlet port of the cell. All the plates have a small terminal for electric connection to be able to easily change the connection to control the number of neutral plate and to achieve a further tests and different operating conditions. In this experiment two conditions were obtained named condition $\mathrm{A}$ and condition $\mathrm{B}$

\section{- Condition A}

Was arranged as positive, 3 neutral plate then negative, so the voltage difference between the two cell will be 3.5 volt and the electrolyze used is sodium hydroxide with a concentration of 10 grams per one liter of distilled water

\section{- Condition B}

Was arranged as positive, 4 neutral plate then negative, so the voltage difference between the two cells will be 2.8 volt using same concentration.

\begin{tabular}{ll}
\multicolumn{1}{c}{ Table 1 } & Engine specifications. \\
\hline Engine model & EY20-3D \\
Engine type & 4-cycle, single cylinder \\
Fuel system & Carburetor \\
Bore $\times$ stroke & $67 \times 52 \mathrm{~mm}$ \\
Max. power & 5.0 HP @ 4000 rpm \\
Max. torque & 9.3 N.M @ 2800 rpm
\end{tabular}

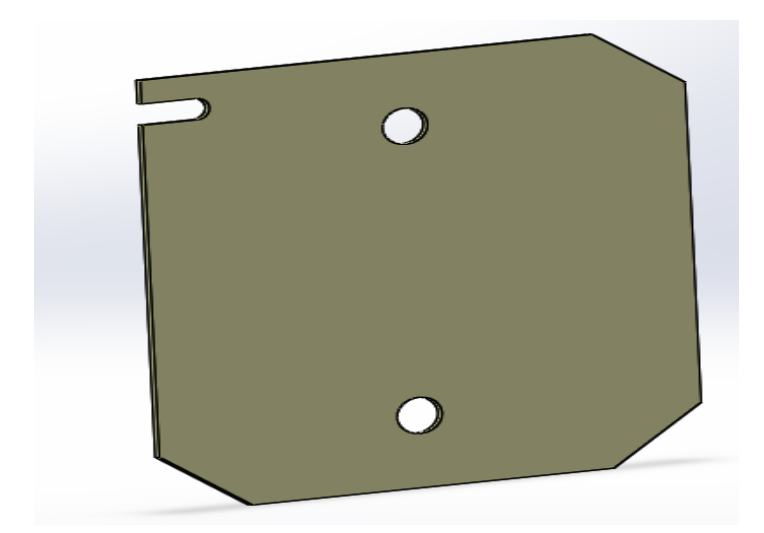

Fig. 1. HHO plate.

\section{- SEPARATION TANK.}

It's a small tank made of plastic and it has a dimension of $20 \times 15 \times 15$ $\mathrm{cm}$, used for separating $\mathrm{HHO}$ gas from water. It has 3 ports, port for gas exit, another port is an inlet port from which a mixture of the generated gas and water have entered it. And the third port is used for water feedback in to the cell. The separation tank is mounted near the cell as shown in Fig. 3. It must be completely closed to ensure no leakage appear during the operation of the cell, beside the material must be suitable for the case of increasing the temperature of the electrolyte, and the material does not have any chemical reaction with the electrolyte fluid.

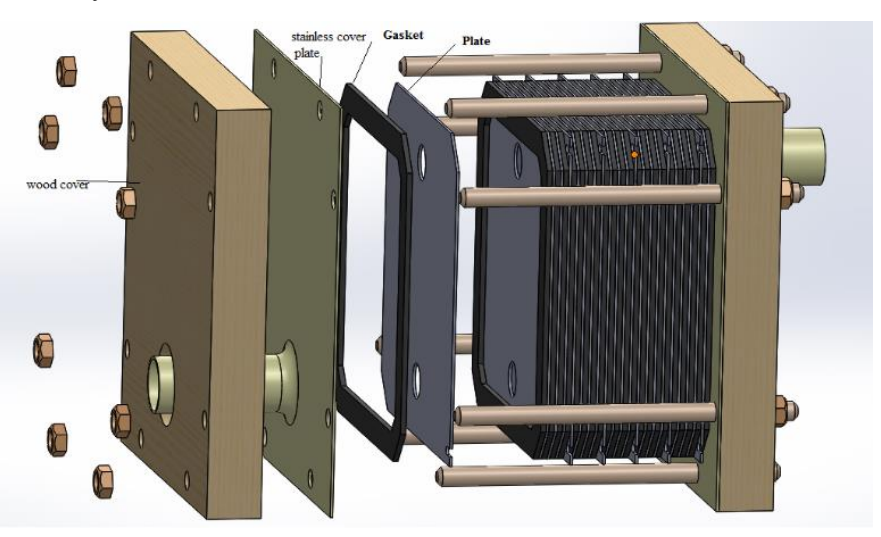

Fig. 2. HHO dry fuel cell construction

\section{- BUBBLER.}

Bubbler is a small water tank used for the purpose of safe operation in order to prevent any back fire from the engine to the $\mathrm{HHO}$ generation system. The bubbler has two ports. Inlet port which conducted to a pipe inside the bubbler, the end of this pipe is located in sufficient distance under the water level and the second port is located in the highest portion of the tank and it used for gas exit 


\section{B. ENGINE TEST RIG}

The engine used is shown in Fig. 2 called (Robin EY 20-3) single cylinder air cooled which specifications are listed in table 1 and it drives centrifugal water pump as a load which specifications are listed on table 2.

\section{Table 2 Pump specifications.}

\begin{tabular}{ll}
\hline Model & PTG210 \\
Type & Centrifugal \\
Suction $\times$ Delivery Diameters & $50.8 \times 50.8 \mathrm{~mm}$ \\
Maximum Delivery Volume & $520 \mathrm{~L} / \mathrm{min}$ \\
Total Head & $32 \mathrm{~m}$ \\
Suction Head & $8 \mathrm{~m}$ \\
\hline
\end{tabular}

The experiment is carried out under different engine speeds of 1200 , $1500,2000,2500,3000$ and $3500 \mathrm{rpm}$. In order to study the effect of HHO gas on the performance of the engine, the engine must be run separately without the cell and then with the connection of the cell. Many engine parameters were measured such as fuel consumption by self-built inclined manometer, exhaust temperature by (Infra-red) IR, water flow rate, water head, engine speed by tachometer and engine emissions by Beckman 530 gas analyzer.

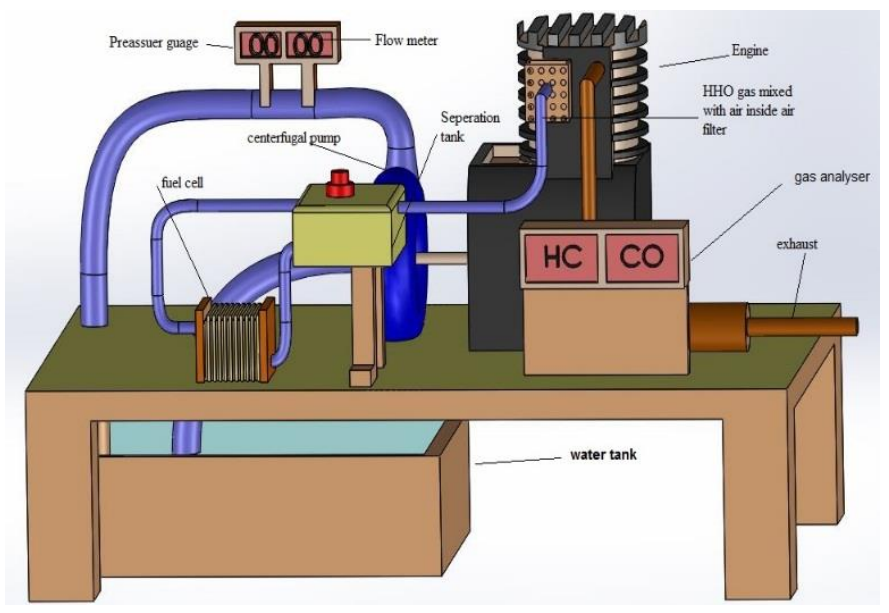

Fig. 3. Experiment test rig

\section{RESULTS AND DISCUSSION}

\section{A. HHO generator}

Before connecting the cell to the intake air of the engine. The cell was tested separately. Fig. 4. Shows the variation of production rate of $\mathrm{HHO}$ generator versus time for period of 90 minutes of operation. It may be illustrated that production rate of $\mathrm{HHO}$ generator increased with time for booth conditions $\mathrm{A} \& \mathrm{~B}$, it reaches $0.14 \mathrm{~L} / \mathrm{min}$ at the end of operation time for condition $\mathrm{B}$ and $0.83 \mathrm{~L} / \mathrm{min}$ for condition $\mathrm{A}$, condition A has 3 neutral plates, so the voltage difference between the two adjacent parallel plate will be 3.5 volt allowing more current to be drawn as shown in Fig. 5. Rather than condition B which has 4 neutral plates dividing the voltage to be 2.8 volt between the two plates.

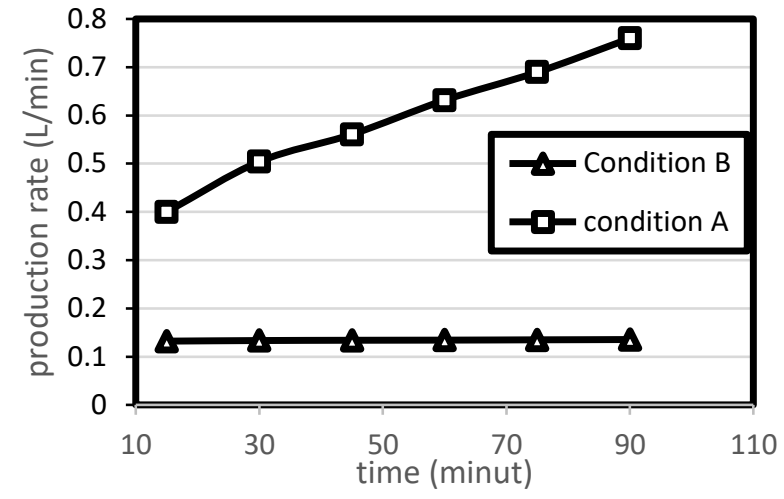

Fig. 4. HHO production rate over time

This will lead to more gas production but it has a side effect on increasing water temperature as shown in Fig. 6 because of the increase in electric current drawn. Increasing the current leads to a subsequent increase in the production rate. However, Part of the electric power is consumed in water heating which increases the water temperature and the reason is the ionic conductivity of electrolyte and surface reaction [17].

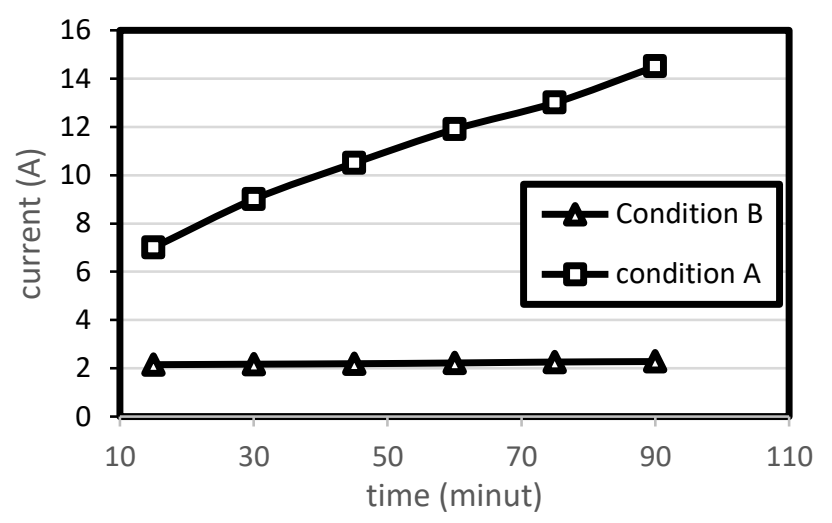

Fig. 5. Variation of drawn cell current with time

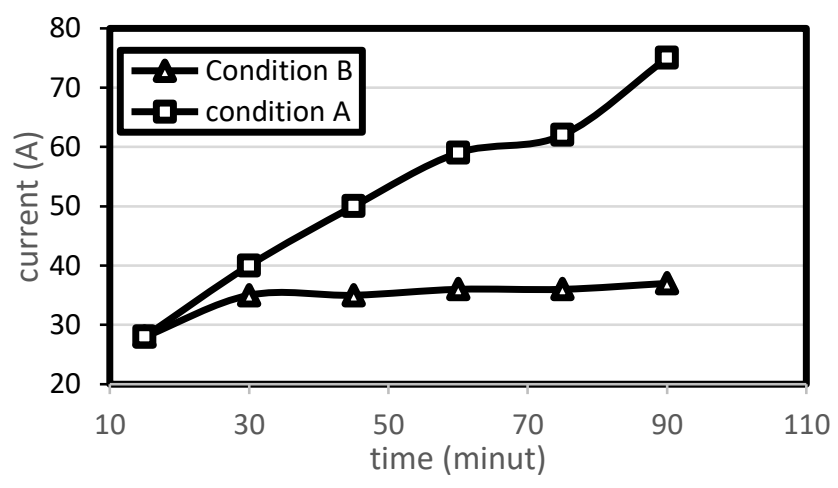

Fig. 6. Variation of cell temperature with time 


\section{B. Engine performance}

Introducing $\mathrm{HHO}$ gas into the intake manifold of the engine has a significant effect on engine performance. Fig. 7 and Fig. 8 shows the effect of $\mathrm{HHO}$ gas addition on the efficiency and B.S.F.C respectively. $\mathrm{HHO}$ gas improve engine efficiency for different engine speeds for the two conditions but it has an unacceptable effect for engine speeds around $2000 \mathrm{rpm}$. HHO increases the average thermal efficiency by $14.3 \%$ and $5.44 \%$ For condition A and B respectively. HHO gas reduced the break specific fuel consumption by $22.1 \%$ and $16.9 \%$ for condition A and B respectively. Engine thermal efficiency and B.S.F.C are considered to be the factor that representing the economics of the engine, introducing $\mathrm{HHO}$ gas into the engine improve these two parameters because of the better advantages of HHO gas rather than gasoline. HHO gas increased the octane rating of gasoline. " octane rating " means how much the fuel can be compressed before it goes to ignition [13] .And the thermal efficiency increases because the combustion will be much closer to the top dead center(TDC) of the engine cylinder[8].

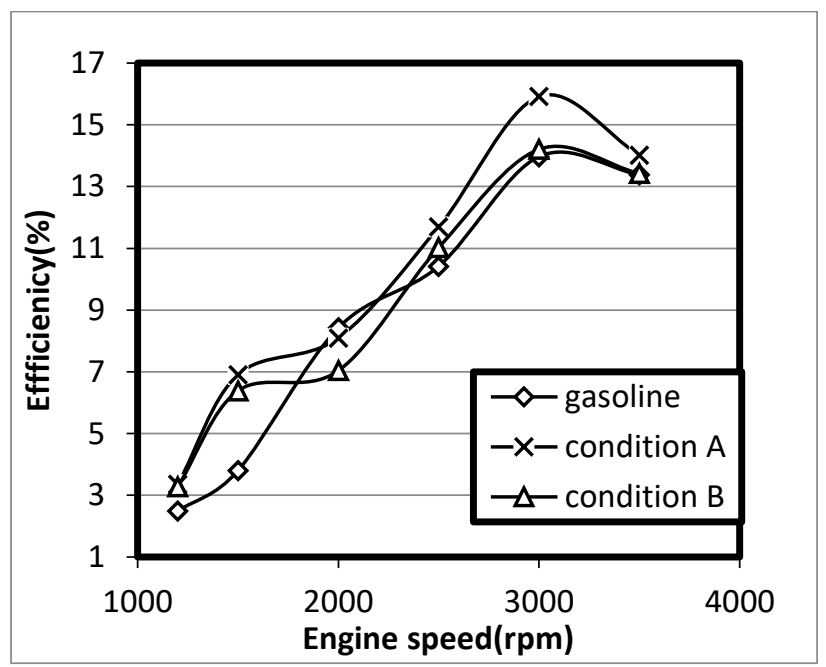

Fig. 7.Variation of thermal efficiency with engine speed.

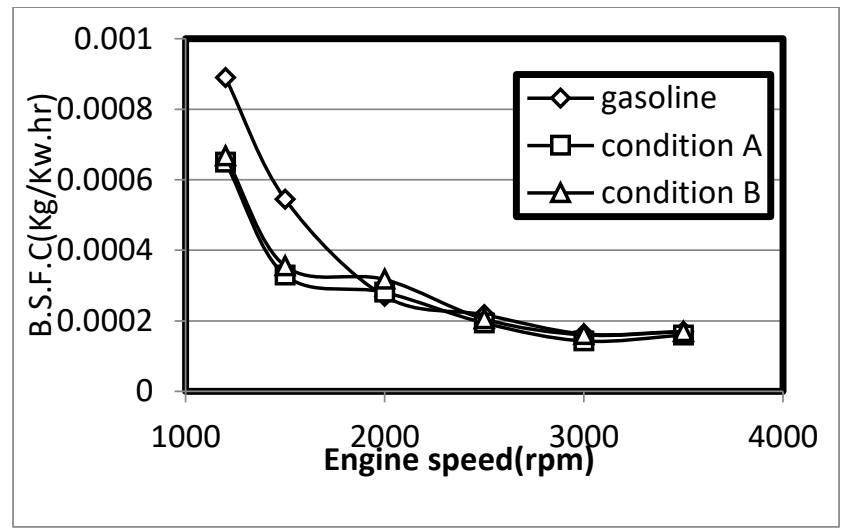

Fig. 8. Effect of HHO gas on break specific fuel consumption for different engine speeds.

\section{Engine emissions}

HHO has a significant effect on engine emissions. Fig. 9.shows the effect of $\mathrm{HHO}$ gas on hydrocarbons (HC) at different engine speeds, an average reduction of 7.2 and $5.5 \%$ for condition $\mathrm{A}$ and $\mathrm{B}$ respectively were obtained, and the average reduction will be $13.6 \%$ for condition B if the value of $2000 \mathrm{rpm}$ was excluded. The curve of $\mathrm{HC}$ shows that, condition A gives more reduction in engine emissions for $\mathrm{HC}$ or $\mathrm{CO}$ because condition A has high production rate compared to condition B but, both the two conditions of HHO gas has a un desirable effect on engine emission and performance around $2000 \mathrm{rpm}$ and this is related to engine adjustable conditions include (carburetor and timing gear) which is lead to uncompleted combustion.

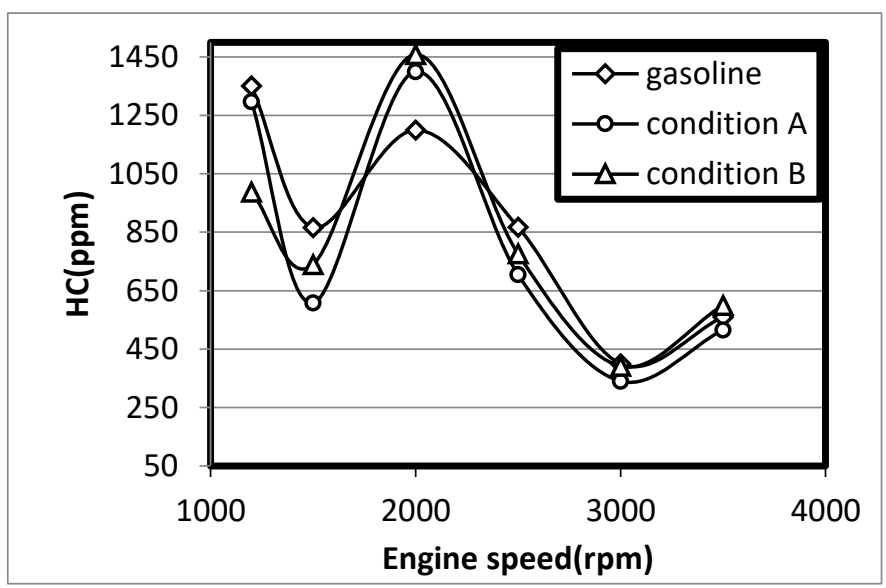

Fig. 9. Effect of HHO gas on HC emissions

Fig. 10. Shows the variations of $\mathrm{CO}$ with engine different speeds, a reduction of $11 \%$ and $4.8 \%$ in average $\mathrm{CO}$ emissions for condition $\mathrm{A}$ and $\mathrm{B}$ respectively. Also analogous $\mathrm{HC}$, the speeds near $2000 \mathrm{rpm}$ the engine became unsteady and gives undesirable effect. The emission of the engine is reduced after adding HHO gas because of the good chemical structure of $\mathrm{HHO}$ gas rather gasoline, hydrogen and oxygen contained in $\mathrm{HHO}$ as two atoms per combustible unit with independent cluster, while gasoline consists of large molecules of hydrocarbons.[3], In addition, HHO gas has high flame velocity.

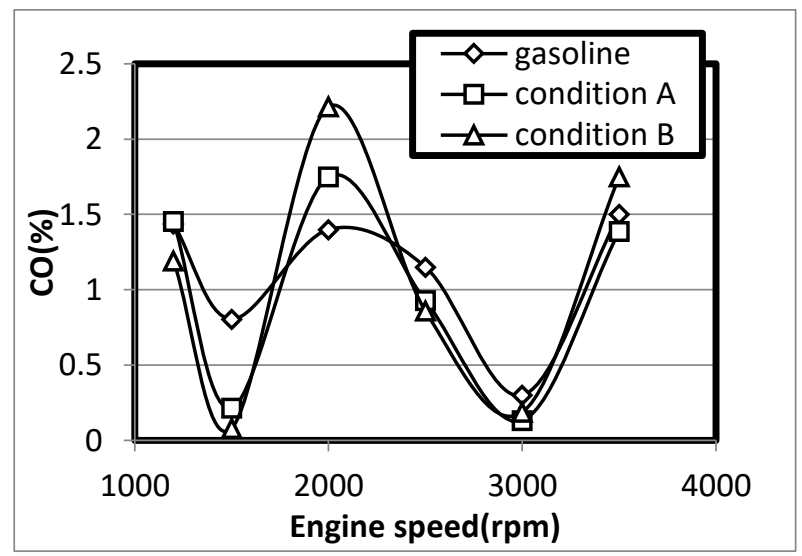

Fig. 10. Effect of HHO gas on CO emissions 
International Journal of Applied Energy Systems, Vol. 2, No. 2, July 2020 ISSN: 2636 - 3712 (Printed Version) ISSN: 2636 - 3720 (Online Version) Special Issue: ICEE-2019

\section{CONCOLOSION}

Two fuel dry cell operating conditions named (condition A and condition B ) were manufactured and tested, then are connected to a 183 CC single cylinder air cooled engine (Robin EY 20-3) in order to evaluate the effect of $\mathrm{HHO}$ gas on the performance and emissions of SI engines, the following conclusions can be written.

- HHO production rate is depend on the number of neutral plates, condition A which has 3 neutral plates gives high production rate rather than condition $\mathrm{B}$ which has 4 neutral plates.

- Reducing the number of neutral plates will increase water temperature.

- $\quad$ The thermal efficiency increased by $14.3 \%$ and $5.44 \%$

For condition A and B respectively with a reduction of $22.1 \%$ and $16.9 \%$ in break specific fuel consumption for condition $\mathrm{A}$ and $\mathrm{B}$ respectively.

\section{REFERENCES}

[1] H. H. Masjuki, A. M. Ruhul, N. N. Mustafi, M. A. Kalam, M. I. Arbab, and I. M. R. Fattah, "ScienceDirect Study of production optimization and effect of hydroxyl gas on a CI engine performance and emission fueled with biodiesel blends," Int. J. Hydrogen Energy, vol. 41, no. 33, pp. 14519-14528, 2016.

[2] S. Wang, C. Ji, J. Zhang, B. Z.-I. J. of H. Energy, and undefined 2011, "Improving the performance of a gasoline engine with the addition of hydrogen-oxygen mixtures," Elsevier.

[3] M. M. El-kassaby, Y. A. Eldrainy, M. E. Khidr, and K. I. Khidr, "Effect of hydroxy ( HHO ) gas addition on gasoline engine performance and emissions," Alexandria Eng. J., vol. 55, no. 1, pp. 243-251, 2016.

[4] V. M. Krishna, "Emissions control and performance evaluation of spark ignition engine with oxy-hydrogen blending," Int. J. Heat Technol., vol. 36, no. 1, pp. 118-124, 2018.

[5] T. Rajasekaran, K. Duraiswamy, M. B.-A. J. E. A. Sci, and undefined 2015, "Characteristics of engine at various speed conditions by mixing of HHO with gasoline and LPG."

[6] R. Sunil, A. Ramakrishna, K. N.-I. J. of Mechanical, and undefined 2014, "Modification of SI engine to HHO engine using HHO generator and its analysis."

[7] S. A. Musmar and A. A. Al-rousan, "Effect of HHO gas on combustion emissions in gasoline engines," vol. 90, pp. 3066-3070, 2011.

[8] A. A. Al-rousan, "Reduction of fuel consumption in gasoline engines by introducing $\mathrm{HHO}$ gas into intake manifold," Int. J. Hydrogen Energy, vol. 35, no. 23, pp. 12930-12935, 2010.

[9] A. C. Yilmaz and K. Aydin, "Effect of hydroxy ( HHO ) gas addition on performance and exhaust emissions in compression ignition engines," vol. 5, pp. 2-8, 2010.

[10] Y. K.-J. of T. Engineering and undefined 2018, "Effect of hydrogen addition at different levels on emissions and performance of a diesel engine," eds.yildiz.edu.tr.

[11] E. Uludamar, E. Tosun, G. Tüccar, ... Ş. Y.-I. J. of, and undefined 2017, "Evaluation of vibration characteristics of a hydroxyl (HHO) gas generator installed diesel engine fuelled with different diesel-biodiesel blends," Elsevier.

[12] T. Nabil and M. M. K. Dawood, "Enabling ef fi cient use of oxy-hydrogen gas ( $\mathrm{HHO}$ ) in selected engineering applications ; transportation and sustainable power generation," J. Clean. Prod., vol. 237, p. 117798, 2019.

[13] T. M. Ismail, K. Ramzy, M. N. Abelwhab, B. E. Elnaghi, and M. A. El-salam, "Performance of hybrid compression ignition engine using hydroxy ( $\mathrm{HHO}$ ) from dry cell," Energy Convers. Manag., vol. 155, no. November 2017, pp. 287-300, 2018.

[14] S. Bari and M. M. Esmaeil, "Effect of $\mathrm{H} 2$ / O 2 addition in increasing the thermal efficiency of a diesel engine," Fuel, vol. 89, no. 2, pp. 378-383, 2010.

[15] Ç. Conker, “A novel fuzzy logic based safe operation oriented control technique for driving HHO dry cell systems based on PWM duty cycle," Int. J. Hydrogen Energy, vol. 44, no. 20, pp. 9718-9725, Apr. 2019.

[16] A. A. Al-Rousan and S. A. Musmar, "Effect of anodescathodes inter-distances of $\mathrm{HHO}$ fuel cell on gasoline engine performance operating by a blend of HHO," Int. $J$. Hydrogen Energy, vol. 43, no. 41, pp. 19213-19221, Oct. 2018.

[17] H. Masjuki, A. Ruhul, N. Mustafi, ... M. K.-I. J. of, and undefined 2016, "Study of production optimization and effect of hydroxyl gas on a CI engine performance and emission fueled with biodiesel blends," Elsevier. 